\title{
Re-Imagining International Human Rights Education in Our Time: Beyond Three Constitutive Orthodoxies
}

Obiora Chinedu Okafor

Osgoode Hall Law School of York University, ookafor@osgoode.yorku.ca

Shedrack C. Agbakwa

Source Publication:

Leiden Journal of International Law. Volume 14, Number 3 (2001), p. 563-590.

Follow this and additional works at: https://digitalcommons.osgoode.yorku.ca/scholarly_works (c) $($ ) $(\ominus$

This work is licensed under a Creative Commons Attribution-Noncommercial-No Derivative Works 4.0 License.

\section{Recommended Citation}

Okafor, Obiora Chinedu, and Shedrack C. Agbakwa. "Re-Imagining International Human Rights Education in Our Time: Beyond Three Constitutive Orthodoxies." Leiden Journal of International Law 14.3 (2001): 563-590.

This Article is brought to you for free and open access by the Faculty Scholarship at Osgoode Digital Commons. It has been accepted for inclusion in Articles \& Book Chapters by an authorized administrator of Osgoode Digital Commons. 


\title{
Re-Imagining International Human Rights Education in Our Time: Beyond Three Constitutive Orthodoxies
}

\author{
Obiora Chinedu Okafor* and Shedrack C. Agbakwa**
}

Keywords: constitutive orthodoxies; international human rights education; Third World; transformation; Western societies.

\begin{abstract}
This article seeks to show that both the conceptualization and practice of international human rights education within the mainstream human rights community has been shaped and framed, with mostly negative consequences, by at least three constitutive orthodoxies: a heaven-hell binary distinction between an all but "perfect" West and an all but "hellish" Third World; a consequent unidirectional traffic of human rights teaching from the West to the rest; and a reliance on the abolitionist paradigm of human rights education. It starts by mapping these orthodoxies, and proceeds thereafter to challenge them as fundamentally problematic and as capable of frustrating the project of progressive human rights education. The article ends by offering an insight into the ways in which international human rights education might be reimagined if it is to have a better chance of achieving its ordinarily laudable mission.
\end{abstract}

The [im]possibility of HRE [i.e., human rights education], then, depends on the modes of struggle which will make both probable and possible the condition and circumstance of their survival, across the globe, in ways which nurture human futures $[\ldots]$. Quite simply, HRE praxis is just another name for human rights struggles.

In the human rights story, the savior is the human rights corpus itself, with the United Nations, Western Governments, INGOs, and Western charities as the actual

* Assistant Professor and SSRC-MacArthur Foundation Fellow on Peace and Security in a Changing World, Osgoode Hall Law School, York University, Toronto, Canada; Visiting Scholar, Human Rights Program, Harvard Law School (April-August 1999 and April-July 2001); LL.B. (Hons), LL.M. (University of Nigeria, Enugu Campus); LL.M., Ph.D. (University of British Columbia, Vancouver, Canada).

We are grateful to the Social Science and Humanities Research Council of Canada for the generous funds (granted to Obiora Chinedu Okafor) that allowed us to conduct the research on which this paper is based. Given the extent to which we have much benefited from the general insights of TWAIL human rights scholarship, we wish to acknowledge our eternal indebtedness to all the scholars who work in that tradition, especially Antony Anghie, Upendra Baxi, Bhupinder Chimni, Karin Mickelson, Makau Mutua, and Balakrishnan Rajagopal. We also acknowledge the excellent research assistance provided by Richelle Samuel and Hanya Soliman.

** Doctoral Candidate, Osgoode Hall Law School, York University, Toronto, Canada; LL.B. (Hons) (University of Nigeria, Enugu Campus); LL.M. (Dalhousie University, Halifax, Canada).

1. See U. Baxi, Random Reflections on the [Im]possibility of Human Rights Education, online at http://www.pdhre.org/dialogue/reflections.html. 
rescuers, redeemers of a benighted world [...]. The savior is ultimately a set of culturally based norms and practices that inhere in liberal thought and philosophy. ${ }^{2}$

Who are better prepared than the oppressed to understand the terrible significance of an oppressive society? Who suffer the effects of oppression more than the oppressed? Who can better understand the necessity of liberation? ${ }^{3}$

\section{INTRODUCTION}

The UN-declared Decade for Human Rights Education has already run half its course. ${ }^{4}$ Given the significance of this decade, its dedication to the specific project of human rights education, we consider this median moment particularly appropriate for taking stock of, and reflecting critically on, the progress of international human rights education, a sub-set of the larger project of human rights education. The necessity for this mid-course evaluation seems even more obvious given the emergent consensus among many human rights scholars that the broader human rights project (of which international human rights education ('IHRE') is an important part) has, so far been characterized by too wide a gulf between "thought and reality, aspiration and achievement." This evaluative exercise is even more important in view of the fact that most serious scholars are now agreed that human rights education is an important means of assuring, in the long term, the observance of the norms of human rights ${ }^{6}$ - and thus the bridging of the perceived gulf between human rights theory and practice.

2. See M. Mutua, Savages, Victims, and Saviors: The Metaphor of Human Rights, 42 Harv. Int'l L.J. 201, at 204 (2001).

3. See P. Freire, Pedagogy of the Oppressed, at 27 (New York: Continuum, 1997). We wish to point out that by citing this passage from Paulo Freire's famous work, we do not mean to subscribe to over-generalized "oppression" and "liberation." We do not view Freire's own work as an example of this pitfall. Nevertheless, we do believe that to "generalize" is not always a pitfall. A certain measure of generalization is imperative in the very use of language. What is important, as always, is a self-reflexiveness regarding its possible negative implications. Again, we do also intend to minimize Freire's self-admitted (though contextual) lack of engagement, in the cited book, with the historical specificities of oppression, especially as it relates to the experiences of subaltern and non-subaltern women. For an important discussion concerning these two questions, see P. Freire \& D. Macedo, A Dialogue with Paulo Freire, in P. McLaren \& P. Leonard (Eds.), Paulo Freire: A Critical Encounter 169-176 (London: Routledge, 1993).

4. See UN General Assembly Res. 49/184 (1994), proclaiming 1995-2005 as the UN Decade of HRE.

5. See P. Kirpal, Human Rights: The Contemporary Situation - New Orientations in Education - Looking Ahead, in UNESCO, Philosophical Foundations of Human Rights 279 (Paris: UNESCO, 1986). See also J. Shand Watson, Theory \& Reality in the International Protection of Human Rights (New York: Transnational Publishers, 1999). For a critique of Watson's arguments, that is sympathetic on this point, see M. Mutua, Book Review and Note: Theory and Reality in the International Protection of Human Rights, 95 AJIL 255 (2001).

6. See K. Pritchard, Political Science and the Teaching of Human Rights, 11 Human Rights Quarterly 459 (1989). 
As defined by Dieter Misgeld:

[...] human rights education is that form of educational activity which is needed in order to maintain and develop conditions conducive to the acceptance and respect for human rights.

For its own part, international human rights education is a vast, wellestablished, and increasingly popular form of human rights education. ${ }^{8}$ Nevertheless, it has not been particularly well noticed in the scholarly literature as a discrete subject of enquiry. Its existence has been virtually concealed by its treatment as a non-discrete form of human rights education. Simply put, IHRE is the conduct of human rights education in a given country by persons from elsewhere, or by their local agents or cohorts. We have thus adopted a very broad definition of IHRE, one that includes, but is not limited to, human rights teaching, human rights proselytization, and other formal and informal modes of international human rights education.

What we want to do in this paper is to identify, tease out, critique, and propose alternatives to, three orthodoxies that we view as constitutive of both the broader human rights discourse as well as the mainstream IHRE discourse and practice. For ease of identification, understanding and analysis, we have decided to refer to these three orthodoxies under the names and styles of (a) the heaven-hell binary, (b) the one-way traffic paradigm, and (c) the abolitionist paradigm.

To his end, we have organized the paper into four major sections, the first being this brief introduction. In Section 2 of the paper, we will map the characteristics and valencies of each of the three orthodoxies, and attempt to challenge the validity and dominance in the IHRE discourse of each of these same three orthodoxies, highlighting in our stride the negative consequences for the broader human rights project of their continued operation. In Section 3, we will attempt to chart a path forward, and explicate the various ways in which these orthodoxies may be transcended, indicating as we go along all the potential benefits of re-imagining IHRE in these ways. The brief summary that appears in Section 4 will conclude the paper.

\section{Mapping and Challenging the Three Orthodoxies}

In this section of the paper, we will attempt to identify and elaborate on the characteristics of the three orthodoxies that underlie mainstream

7. See D. Misgeld, Human Rights and Education: Conclusions from Some Latin American Experiences, 23 Journal of Moral Education 239 (1994). For a more extended definition, see L. Frost, Human Rights Education for Indigenous Peoples: Teaching Whose Human Rights?, 7 St. Thomas Law Review 699, at 702-703 (1995).

8. See Frost, id., at 710-714. 
theories and practices of IHRE in order to shed light on the nature of these orthodoxies, and to demonstrate their nature as dominant, orthodox, and constitutive conceptions and practices of IHRE. Additionally, we will demonstrate the various ways in which each of the three orthodoxies and the IHRE projects that are framed by these orthodoxies are deeply flawed. Accordingly, our beef in this section of the paper is both with the existence of some kind of distinctions among societies based on their level of respect for human rights, and with the absolutism of much of the language of these typologies, their binary nature.

\subsection{The heaven-hell binary}

This binary dichotomy, that basically splits the globe into two conceptual communities, the one "hellish" and the other "heavenly," is employed all-too-often by mainstream human rights discourse as well as by IHRE theorists and practitioners. Those who employ it basically view our world as, for the most part, constituted by two types of societies, the one "respective of human rights," and the other "violative of human rights." Thus, a relatively extremist typology of states is employed all-too-often in order to sieve "human rights respecting societies" from "human rights violating societies." The material and psychological conditions in the states that are classified as belonging to the first category are viewed as heavenly and as ideal, while the conditions in the states that are classified as belonging to the second category are viewed as hellish, and as far from the ideal as possible. This is the first of the two related dimensions of this heavenhell binary that is employed so often in broader human rights discourse, as well as in IHRE discourse. In this specific context, both the "human rights heaven" and the "human rights hell" are "places" or geographical locations. On the one hand, "Western" societies are usually constructed as heavenly places that are without significant human rights violations, and are therefore as virtually heavenly places. On the other hand, "Third World" states are almost always viewed as hellish places that are virtually constituted by incessant epidemics of the most horrendous sorts of human rights violations.

The other dimension of this binary distinction is textual. The existing human rights corpus, consisting of all the international treaties and instruments, is too often conceived as heavenly and infallible. It is viewed as heavenly largely because it presents a particular picture of the good life that ought not be challenged at all, and is in any case, incontrovertible. Gospel like, it is a final set of truths. Opposed to this heavenly set

9. We use this expression much in the same sense as that expression has been used by Balakrishnan Rajagopal as a set of "counter-hegemonic discursive sites," and by Karin Mickelson, as "a chorus of voices." See B. Rajagopal, Locating the Third World in Cultural Geography, (1998-1999) Third World Legal Studies 1; and K. Mickelson, Rhetoric and Rage: Third World Voices in International Legal Discourse, 16 Wis. Int'1. L.J. 353 (1998). 
of texts are other languages of human dignity, other traditions and cultures, and other tests that seek to project alternative visions of the good life. These texts and cultural standards are almost always viewed as virtually hellish, as much closer to recommending a vision of a hellish life than to presenting a vision of the good life ${ }^{10}$ Examples of these include the constitutive texts of Islam, Hinduism, and African traditional religions. Thus, in the broader mainstream human rights discourse, if "heaven" and "hell" are sets of places, they are also represented in sets of texts.

The existence of this "heaven-hell" binary distinction as a constitutive element of both the broader mainstream human rights discourse as well as of the IHRE discourse is easily illustrated. For instance, in their otherwise thoughtful paper on the work of transnational human rights organisations, Jackie Smith and Ron Pagnucco did embrace this kind of binary distinction between a supposedly heavenly Western world and a hellish Third World. In discussing the reasons for the dominance of Western-based human rights organisations globally, they averred most confidently that:

[...] the most abhorrent human rights violations occur in this region [i.e., the Third World, and that] [...] it is such repression that makes it less likely for NGOs to thrive there. ${ }^{11}$

While these scholars seem to recognize that human rights violations occur in the Western world, their conclusion that the most abhorrent forms of these violations largely occur in the Third World is symptomatic of the operation of the heaven-hell binary in much of human rights and IHRE discourse.

Similarly, the USA-based National Center for Human Rights Education has openly admitted the existence of this kind of extreme binary in IHRE discourse and practice. In their own words:

There is no global human rights movement in the United States. To the majority of Americans, human rights violations occur overseas. ${ }^{12}$

10. For example, see Rhoda Howard's now famous position that because they authorize brutish and cruel actions, no non-Western system of social justice can guarantee human dignity. See R. Howard, Cultural Absolutism and the Nostalgia for Community, 15 Human Rights Quarterly 24 (1993). For critiques of this position, see P. Fitzpatrick \& E. Darian-Smith, Laws of the Postcolonial: An Insistent Introduction, in P. Fitzpatrick \& E. Darian-Smith (Eds.), Laws of the Postcolonial (Ann Arbor: University of Michigan Press, 1999); and M. Mutua, The Banjul Charter and the African Cultural Fingerprint: An Evaluation of the Language of Duties, 35 Virginia Journal of International Law 338 (1995).

11. See J. Smith \& R. Pagnucco, Globalizing Human Rights: The Work of Transnational Human Rights NGOs in the 1990s, 20 Human Rights Quarterly 379, at 386 (1998).

12. See http://www.pdhre.org/chre/index.html. L.J. Ross, Beyond Civil Rights: A New Vision for Social Justice in the United States, 2(1) Human Rights Dialogue 10, at 11 (2000), has also observed that 
For her own part, Ellen Dorsey makes a distinction between the "rightsresponsive" societies of the West, and the "authoritative systems" of the Third World. ${ }^{13}$ Dorata Gierycz is of the view that human rights violations against women in the Third World are "particularly alarming" much more so than in the West. ${ }^{14}$

In addition to the foregoing instances, there are more sophisticated brands, particularly evident in the neo-liberal position on human rights, which perpetuates the heaven-hell orthodoxy in a much more subtle and complex way. The neo-liberals do not simply make a clear-cut (physical) heaven-hell distinction. Rather they usually argue that the liberal democratic philosophy and the human rights ideology/philosophy are "final truths" that apply universally throughout the world, including the Third World, while at the same time denying the Western rootedness of these ideologies. ${ }^{15}$ For instance, Thomas Franck recently argued that:

The human rights canon is full of rules that, far from being deeply rooted in Western culture, are actually the products of recent developments - industrialization, urbanization, the communications and information revolutions - that are replicable anywhere $[\ldots]$. They are hardly Western $[\ldots] .{ }^{16}$

By denying the Western basis of the ideology of human rights, Prof. Franck unsuccessfully sought to situate himself on a supposed neutral ideological ground. Yet, his carefully refined heaven-hell orthodoxy remained evident in his near hellish depiction of the human rights situation of the so-called cultural exceptionalists, those who reject the lock, stock, and

Americans have been conditioned by the corporate news media, international human rights organizations, and our government to associate human rights violations with [...] the lack of freedoms in other countries. This portrayal often prevents [Americans] from seeing injustices in the United States as human rights violations.

See also, Hans A. Linde's comments on P.L. Hoffman, The Application of International Human Rights Law in State Courts: A View From California, 18 Int'1 Law. 61, at 77 (1984), emphasizing that

it is largely taken as an article of faith that the United States provides the best protection for human rights in the world. If there are any rights recognized in international law that are not recognized in U.S. law [American] people may assume that there is a good reason for that nonrecognition.

13. See E. Dorsey, Charter Making and Participatory Research, in G.J. Andreopoulos \& R.P. Claude (Eds.), Human Rights Education for the Twenty-First Century, at 140 (Philadelphia: University of Pennsylvania Press, 1997).

14. See D. Gierycz, Education on the Human Rights of Women as a Vehicle for Change, in Andreopoulos \& Claude, id., at 112 .

15. See, for instance, T.M. Franck, Is Personal Freedom a Western Value?, 91 AJIL 593 (1997), denying the Western quality of the human rights regime constructed after World War II.

16. T.M. Franck, Are Human Rights Universal?, 80 Foreign Affairs 191, at 198 (2001); see also at 202 where he asserted that human rights do not "represent Western cultural imperialism; instead they are consequence of modernizing forces that are not culturally specific." 
barrel universalization of Western cultural values. ${ }^{17}$ By the blanket extension of this set of ideas that were formulated based on a Western set of experiences to the 'Third World' and framing them as universal ideas, and eternal truths, the neo-liberals assume, even if implicitly, that there are "heavens" (with heavenly ideas), and a 'hell,' with ideas that are hellish and need to be remedied by the wholesale adoption of their heavenly ideas.

Needless to say, this heaven-hell binary is employed as much by Third World scholars as by Western scholars. For instance, our own very respected teacher and mentor, Gaius Ezejiofor, is convinced that only "third world governments" merit the dishonour of being tagged as possessing "poor human rights records." 18

And lastly, an excellent illustration of the ways in which the heavenhell binary is employed in human rights discourse is constituted by the rationale offered to the Human Rights Committee ('HRC') by the USA for that country's indication of several severely oppositional understandings, declarations, and reservations as part of its instrument of ratification of the International Covenant on Civil and Political Rights ('ICCPR') ${ }^{19}$ First of all, it is important to note that it took the USA over two decades to ratify the ICCPR (a treaty that it had helped draft), and even so, when it came to ratification time, it did so with "a great deal of discomfiture." 20 On all the issues on which USA law and mores fell short of the relevant international human rights position, it filed four understandings, five declarations, and five reservations that sought to excuse its non-compliance with the ICCPR by arguing that the contemporary legal position in the USA was adequate ${ }^{21}$ and ought not, as such, to be interro-

17. Id. While urging vigorous international action against the exceptionalism of the supposed human rights hells, Prof. Thomas Franck did not see such a measure fit enough for the reversal of the deep-rooted US mainstream scepticism and rejection of the universality of global human rights norms. Apparently, he did not see any reason for 'wasting' international efforts on a supposed human rights heaven. See id., at 204.

18. See G. Ezejiofor, The Development of the Concept of Human Rights: Definition and Philosophical Foundations, in A.O. Obilade \& C. Nwankwo (Eds.), Text for Human Rights Teaching in Schools 1, at 16-19 (Lagos: Constitutional Rights Project, 1999).

19. For critical reflections on these reservations as well as on the USA's initial report to the HRC, see U. Baxi, 'A Work in Progress'?: The United States' Report to the United Nations' Human Rights Committee, 35 Indian Journal of International Law 34 (1995); and J. Paust, Avoiding Fraudulent Executive Policy: An Analysis of Non-Self-Execution of the Covenant on Civil and Political Rights, 42 DePaul Law Review 1257 (1993). See also Lawyers Committee for Human Rights, Statements on US Ratification of the CCPR, 14 Human Rights Law Journal 125 (1993). For an attempt to justify the reservations, see D.P. Stewart, U.S. Ratification of the Covenant on Civil and Political Rights: The Significance of the Reservations, Understandings and Declarations, 14 Human Rights Law Journal 77 (1993). It is important to note that Belgium, Denmark, France, Finland, Germany, Norway, Portugal, Spain, and Sweden have filed objections to the USA's reservations. See Baxi, supra, at 35. For the text of US Reservations, Understandings and Declarations, see 14 Human Rights Law Journal 123 (1993).

20. See Baxi, id., at 34 .

21. See Initial Report of the USA to the Human Rights Committee CCPR/C/81/Add.4 (State Party Report) (24 August 1994). 
gated by the HRC. Yet this is the very same kind of argument that it refuses to condone in what Upendra Baxi has described as its "annual invigilation" of the human rights situation in other countries (especially those of the aid-recipient Third World states). ${ }^{22}$ What is more, the USA also argued that there was no need to make the ICCPR self-executing (or directly enforceable) in the USA because, in the view of its Senate, its domestic legal system "sufficiently protects the rights guaranteed in the ICCPR." ${ }^{23}$ This is the kind of argumentative position that no less a scholar than Jordan Paust has described as attractive of "serious dishonour to the United States." ${ }^{24}$ For if this position was accurate, the USA would not have found it necessary to "protect" its national system from the ICCPR by making the latter non-self-executing, and by indicating a total of fourteen reservations, declarations, and understandings to that treaty! Not surprisingly, as Upendra Baxi has also shown, much of the USA's initial report offered an account of how the USA's constitution has shaped the ICCPR, rather than how the "attainments and shortfalls" of USA society may be measured by the text and context of the ICCPR. ${ }^{25}$ In all of this, the dominant overarching attitude of the USA Congress and the officials that wrote the initial report to the HRC has been that the laws and social context of the USA are some kind of virtual human rights heavens against which all other societies and all other texts (sometimes including the ICCPR!) are to be measured. ${ }^{26}$ Implicit (and sometimes explicit) in the enunciations of this strange logic is an understanding that there are other societies in the world, i.e., human rights hells, to which the ICCPR ought properly to be applied (otherwise the USA's commendable role in helping to craft the treaty in the first place would not make sense at all). Needless to say, a heaven-

22. See Baxi, supra note 19 , at $37-38$.

23. Id. In its letter to the US Senate Foreign Relations Committee, the Lawyers Committee for Human Rights, rightly in our view, argued that the US's position amounted to outright refusal to "commit itself to do anything that would require change in the present U.S. law or practice." See Lawyers Committee for Human Rights, supra note 19, at 125.

24. See Paust, supra note 19 , at 1283 .

25. See Baxi, supra note 19 , at 34 . A further insight to this mindset may be gleaned from the USA's reservation to Art. 7 of the ICCPR, to wit:

That the United States considers itself bound by Article 7 to the extent that 'cruel, inhuman or degrading treatment or punishment' means the cruel and unusual treatment or punishment prohibited by the Fifth, Eight and/or Fourteenth Amendments to the Constitution of the United States.

See U.S. Reservations, supra note 19, at 123 (emphasis supplied).

26. This is hardly surprising for, as Forsythe and Rieffer have pointed out,

Americans generally see themselves as an exceptionally good people who have compiled an enviable record of protecting personal freedom [...] [and,] [s]ince the time of George Washington, [...] the United States has professed to want to teach the rest of the world $[\ldots]$ about the benefits of human rights and liberal democracy.

See D.P. Forsythe \& B.A.J. Rieffer, US Foreign Policy and the Enlarging Democratic Community, 22 Human Rights Quarterly 988, at 989 (2000). 
hell binary typology of places and texts is too often employed in both the broader mainstream human rights discourse and the IHRE discourse.

Our major objection to the sort of typological extremism that is evinced by the use of the heaven-hell binary in mainstream human rights and IHRE discourse is that it too often and too easily glosses over the quite palpable omnipresence of oppression and cruelty in every single society or polity in the world. Our contention is that there is no place that is a human rights heaven. As Pauline Hountondji has demonstrated, human rights is nowhere a "mass cultural fact." ${ }^{27}$ This is not to suggest, of course, that some societies have not at specific times been much more cruel than others. Our beef here is with the near absolutism of the classification of human polities into "human rights respective" and "human rights violative" societies - into human rights heavens and human rights hells. This is a typology of human polities that all-too-often takes or evokes an extremely dim view of most Third World societies while at the very same time taking an overly optimistic and benign view of most Western societies. This sort of absolutist typology of states is not sustainable by a factual enquiry into the nature of human societies, be they classified either as Western or Third World. Surely, it does not require much imagination to sense that in this case, the correct picture has to be much more complicated. Let us now attempt to further flesh out this objection.

Every Western state that we know of is characterized to a certain extent by the violation of human rights. ${ }^{28}$ As Makau Mutua has noted, "Western countries, like the United States, are notorious for their violations of the civil rights of racial minorities and the poor." ${ }^{29}$ Given its pre-eminent status as the most powerful of the western bloc of nations in our time, an examination of the human rights situation in the USA will serve as a good illustration of the presence of human rights violations in the Western states that are too often presented as human rights heavens. For instance, despite its horrendous abuse over several centuries of its aboriginal population, sometimes culminating in the total elimination of an entire aboriginal nation, ${ }^{30}$ the US Government still arrogates to itself (with no clear basis in law) virtually absolute powers to extinguish aboriginal title to land and resources in that country. ${ }^{31}$ Again, despite its terrible enslavement and brutalisation, over a number of centuries, of its millions of citizens of African origin, the USA still permits hate speech directed against that

27. P. Hountondji, The Master's Voice - Remarks on the Problem of Human Rights in Africa, in UNESCO, Philosophical Foundations of Human Rights 319, at 320-332 (Paris: UNESCO, 1986).

28. On this and similar questions, see Kirpal, supra note 5, at 279-300.

29. See Mutua, supra note 2, at 217.

30. See N. Chomsky, The United States and the Challenge of Relativity, in T. Evans (Ed.), Human Rights Fifty Years On: A Reappraisal 24, at 25-26 (Manchester: University Press, 1998), noting the US treatment of "that hapless race of native Americans" which are being exterminated "with such merciless and perfidious cruelty."

31. See Baxi, supra note 19 , at 45 . 
and other vulnerable minority groups to flourish, almost unchecked, based on a bizarre notion of free market-like "free" speech. ${ }^{32}$ The situation in this last respect has been so bad that Upendra Baxi has accused the USA Government of the relevant periods of succumbing to a "monstrous conjugation of Pentagon and Ku Klux Klan moralities." ${ }^{33}$ Even more worrisome is the USA's insistence, against all humanist reason, on executing many of its convicts, including minors. ${ }^{34}$ Moreover, as Baxi has again informed us:

The arbitrary nature of capital punishment is evident from a disproportionate award to racially vulnerable individuals. As late as 1990 the United States General Accounting Office found [...] that in $82 \%$ of the cases race of the victim had an impact on sentencing [...]. The much vaunted due process is not, nor can ever be, color blind [in the United States]. ${ }^{35}$

Similarly, the status of women in the public life of the USA remains quite troubling. According to Baxi, in various sectors of public life in the USA, women's representation ranges only between $10-20 \%$ of the total number of positions (when they constitute about $50 \%$ of the population). ${ }^{36}$ This compares most unfavourably with the situation in many Third World countries. ${ }^{37}$

Concomitantly, every Third World state that we know of is characterized to a certain extent by violations of human rights. As Makau Mutua has recently argued:

Admittedly there are more undemocratic states in the Third World than in the developed West. Third World despots have acted with impunity. Violations of civil and political rights and the plunder of Third World economies by their leaders are common and flagrant. ${ }^{38}$

Thus, the argument is not necessarily that the human rights conditions in the Third World are either ideal or even at par with the situation in Western states. We do recognize that there is a hellish dimension to the lives of the majority of the inhabitants of the Third World. However, we also recognize the fact that such hellish conditions are not absolute. Third World states are hells and heavens to varying extents, depending on whom you ask. So are Western states. The extent to which human rights are violated in most Western states may in fact be much lesser than the extent to which

32. Id., at 42 .

33. Id.

34. Id., at 39. For a detailed consideration of this phenomenon, see Interim Report of the UN Special Rapporteur on Extra-Judicial, Summary, or Arbitrary Executions (prepared by Bacre Waly Ndiaye), A/51/457 (7 October 1996).

35. Baxi, supra note 19 , at 41.

36. Id., at 48 .

37. Id.

38. Mutua, supra note 2, at 217. 
they are violated in most Third World states, but surely one's perspective on this matter is shaped both by one's imagination of what human rights are, and by whose human rights are considered important in the society in question? Only what Baxi has described as genesis amnesia ${ }^{39}$ in relation to the oppressive conditions in which vulnerable groups (such as blacks and asylum seekers) too often live in many Western countries can explain a contrary view in this respect. Certain places are better at protecting certain kinds of human rights, but there is no place known to us that merits the heavenly tag.

As importantly, our other objection to the heaven-hell binary is that if there is no place that we know of that is a human rights heaven, there is also no human rights text that is so heavenly as to be beyond question, critique, and revision or enlargement. This is so because there is no such text that is politically innocent - no matter how abstract the principles that it enunciates. Every human rights text has been shaped by a number of social, political, and economic forces. Makau Mutua and a number of other scholars have demonstrated this point so convincingly that it will be redundant to rehash the relevant arguments in this short paper. ${ }^{40}$ But suffice it to say that several perspectives on human rights exist, and have always existed. For example, until recently, social and economic rights were not even on the agenda of international human rights and IHRE groups. Moreover, despite the inroads that have been made by other philosophical positions within the human rights and IHRE movements, the main stock of the standards that we today view as the human rights corpus were crafted with an overt (and sometimes covert) Liberal philosophical bias. ${ }^{41}$ Thus, we agree with Baxi that:

There is no non-contested discursive site to be named 'huper rights' [i.e., human rights] and human rights instruments [i.e., human rights texts] remain contested sites. ${ }^{42}$

Thus far, we have shown that the heaven-hell binary is flawed. What remains to be done in this sub-section is to demonstrate how this flaw constitutes a problem for IHRE. What sorts of problems are created by the use of this binary in IHRE discourse?

The main problem with the use of this heaven-hell binary in IHRE discourse is that it contributes to the alienation from the human rights message many addressees of IHRE experience, thus detracting from the effort to generate a measure of mass cultural legitimacy for the human

\footnotetext{
39. See Baxi, supra note 19 , at 46.

40. For instance, see Mutua, supra note 2, at 217; M. Mutua, The Ideology of Human Rights, 36 Virginia Journal of International Law 589 (1996); A. Anghie, Francisco de Vitoria and the Colonial Origins of International Law, 5 Social and Legal Studies 321 (1996); and Hountondji, supra note 27.

41. See Howard, supra note 10 , at 315.

42. See Baxi, supra note 1 , at 7.
} 
rights project. The real message of IHRE is all-too-often occluded by the operation of this binary. This is precisely because the (usually Western) IHRE practitioner or participant who deploys this binary comes across as, at best arrogant, and at worst disingenuous. She/he is too easily unmasked as presenting a factually incomplete sub-text of Western human rights superiority and perfection. At the same time, it remains all too clear to her or his Third World "students" that this absolutist sub-text is without a sound basis in either fact or reason. This IHRE "teacher" is too easily unmasked as presenting an incomplete sub-text of near absolute Third World inferiority and imperfection as the basis of her "right" to instruct the Third World on the ethos and virtues of human rights. This kind of geopolitical tension is avoidable and unnecessary, but where it is present, it functions to erode the already tenuous mass legitimacy being suffered by the human rights project in most areas of the Third World. ${ }^{43}$ This tenuous mass legitimacy of the human right project is thus rendered even shakier by the widespread use of a factually inaccurate sub-text that (in near absolute terms) paints one part of the globe as heavenly, and the other as hellish. And the problem is exacerbated by the fact that most of the contradictions in the adherence of Western societies to human rights are all very public and quite easily exposed. For instance, an IHRE praxis that (as it ought to) celebrates the Nuremberg trials and the Universal Declaration on Human Rights ('UDHR'), too often glosses over the irony of certain Western colonizing powers pushing for those trials to be held, and for the UDHR to be crafted, while at the very same time brutalizing and exploiting their colonial subjects in Africa and Asia, ${ }^{44}$ as well as subjecting their own citizens of African descent to the worst forms of slavery and brutal social subjugation. Again, how about the tragic irony of certain Western states fuelling proxy civil wars within certain African states that involve massive violations of human rights and claiming a right of humanitarian intervention in those same states in order to "resolve" the "ethnic" conflict? The point is that the heaven-hell binary collapses readily when interrogated for the factual underpinnings of its absolutist pretensions. Not being based on reality, it is not a suitable philosophical posture for any human rights project that hopes to gain widespread legitimacy among historically sceptical Third World mass populations. It should not as such form the basis for an IHRE praxis that seeks to be relevant and sustainable in the Third World.

43. For an explanation of the reasons for the difficulty that the human rights project has experienced in its attempt to gain mass legitimacy in the Third World see C.A. Odinkalu, Why More Africans Don't Use Human Rights Language, 2(1) Human Rights Dialogue 3, at 3-4 (2000).

44. See Mutua, supra note 2, at 211. See also E.K. Quashigah \& O.C. Okafor, Toward the Enhancement of the Relevance and Effectiveness of the Movement for the Securement of Legitimate Governance in Africa, in E.K. Quashigah \& O.C. Okafor, Legitimate Governance in Africa: International and Domestic Legal Perspectives 539, at 553 (The Hague: Kluwer Law International, 1999). 
The other problem with the absolutism of the heaven-hell binary is that it functions in ways that hinder the cross-fertilization of human rights ideas and thinking across the Western-Third World (or North-South) divide. Since this binary is based on the notion of a neat and bright line that separates the supposedly near perfect Western human rights world from a supposedly grossly imperfect Third World, it creates the impression, conscious or unconscious, that in the area of human rights, the Western world has nothing to learn from the Third World. For, what can imperfection teach perfection that is useful? What can the perfect learn from the grossly imperfect? What can heaven glean from its contact with hell that is valuable? However, by functioning in ways that tend to mute the potential flow of human rights ideas from the Third World to the Western world, the heaven-hell binary hampers good faith attempts to construct a truly cosmopolitan human rights ethos - a project that has now been more widely endorsed within the human rights movement. ${ }^{45}$ This situation is rather unfortunate precisely because a human rights dialogue in search of viable cosmopolitan consensus cannot be a mere monologue in which the Western world view is uncritically proselytized without it benefiting from ideas that flow from the Third World. Human rights dialogue cannot be a one-way traffic. The perils of a "one-way traffic" kind of human rights discourse will be elaborated in the next sub-section.

\subsection{The one-way traffic paradigm}

Adherence to this paradigm (chiefly constituted by a lop-sided Third World focus) is a logical end product of a conceptualisation of the human rights situation around the globe that is framed by the heaven-hell binary. For, if certain places and texts are almost entirely beyond reproach in human rights terms, and if it is in those places that the languages and texts of human rights have been crafted and honed, and if the situation in the other places are viewed as largely hellish, and if these other hellish places must be given the benefits of a human rights culture, then it seems quite logical that the ideas and practices of human rights must flow exclusively from the places and texts that are considered "human rights heavens" in the direction of the places and texts that are viewed as "human rights hells." Indeed, Paulo Freire did recognize this kind of linkage between the construction of a place or people as hellish, and the creation of a justification for their reformation or re-education by the peoples of the places that have been constructed as heavenly. Speaking of a traditional teacher-student relationship, he posited that "by considering their [student's] ignorance absolute" a teacher "justifies [her or] his existence," 46 as well as the exclusive flow of information and knowledge from teacher to student (and

45. For instance, see B. de Sousa Santos, Toward A New Common Sense, at 337-352 (New York: Routledge, 1995)

46. See Freire, supra note 3, at 53. 
never vice-versa). The more ignorant the "student" is the more the "teacher" is needed. And the more hellish and benighted a place or text is, the more it needs to be elevated by "teachers" from a heavenly place, using texts that are heavenly. Similarly, by constructing the Third World in virtually absolute terms, as a hellish place, the Western "teacher" of human rights, i.e., the IHRE enthusiast, justifies and secures her or his own existence and position, as well as secures the unidirectional flow of human rights knowledge from the Western world (the teachers) to the Third World (the students). This linkage applies despite explicit denials on the part of scholars such as Rhoda Howard that this unidirectional exportimport vision of human rights proselytisation is necessarily entailed by an adherence to a world view that paints the world in "black" and "white" terms. ${ }^{47}$ Let us now illustrate this extended point.

The first evidence we want to offer in favour of the existence and nature of this one-way traffic paradigm in both the broader mainstream human rights discourse and the IHRE discourse is the fact that almost all the energies of the Western human rights movement, which is by far the most dominant wing of the global human rights movement, is devoted to human rights activism in the Third World. ${ }^{48}$ These Western human rights groups have been, as Makau Mutua has shown, virtually inactive in the Western world. ${ }^{49}$ When they have focused on the Western world at all, their work has been "sparse and episodic." 50 And this has been so despite the notoriety of many Western states regarding, inter alia, the violations of the rights of their racial minorities, immigrants, refugees and the poor, as well as the commonplace occurrence of abuses such as wife-murder and domestic battery in many parts of the Western world (as in the Third World). ${ }^{51}$ As Hope Lewis and Isabelle Gunning have noted:

Women's human rights activism in the United States tends to focus on women outside the U.S., or on women from other cultures who enter the U.S. as immigrants or asylum-seekers. Attention centers on condemning exotic violations that occur in foreign countries. ${ }^{52}$

Similarly, the collection of human right information in, and on, the Third World has almost always been focused on the human rights violations that occur in those societies, and almost never about the human rights standards and knowledge that are held dear by these societies. For this reason, the seminal work that has been done by a number of African

47. See Howard, supra note 10, at 336-337.

48. See Smith \& Pagnucco, supra note 11, at 386.

49. See Mutua, supra note 2, at 216.

50. Id., at 217 .

51. Id.

52. See H. Lewis \& I.R. Gunning, Cleaning Our Own House: 'Exotic' and Familial Human Rights Violations, 4 Buffalo Human Rights Law Review 123 (1998) (emphasis supplied). 
scholars ${ }^{53}$ regarding the human rights or human rights-like philosophies of many African societies has been all but ignored by the mainstream human rights and IHRE communities. Yet many other African scholars and activists have made the case that there is much that the human rights movement, as well as IHRE praxis, can gain by engaging with these traditional knowledges. ${ }^{54}$ For example, have IHRE projects in the Igbo areas of Nigeria not much to gain from an understanding of the traditional republican democratic ethos that survives to this day in those areas of Nigeria? Have IHRE projects in Botswana not much to gain from an understanding of the functions and effect of the vibrant Tswana Kgotla ethos that survives to this day?

The second set of evidence that we want to offer is the negative reaction of the USA, a Western country that is often viewed as exemplary, when faced with outside scrutiny and analysis of its human rights record. For instance, as Upendra Baxi has noticed, its Initial Report to the Human Rights Committee ('HRC') (a body established by the International Covenant on Civil and Political Rights ('ICCPR') to monitor the compliance of states parties with the standards set by that treaty) can be best described as a struggle to "submit itself to the gaze of the human rights world." 55 The question then is: why a struggle? Why could the USA not simply submit itself to the gaze of the human rights world without exhibiting such great discomfort? The answer seems to lie in Rosalyn Higgins' famous comment that many Western states tend to think of the ICCPR and the work of the HRC as properly directed at Third World states but not to them at all. ${ }^{56}$ The Western states that share this view do tend therefore to subscribe to the one-way traffic paradigm in the sense that they view the transmission of human rights norms as something that ought to flow exclusively from either the UN (which they virtually dominate) or themselves in the direction of the Third World. Concomitantly, these states do not usually welcome the scrutiny of their human rights records by either the UN or by the Third World states that are so minded. That is the chief reason why much of the Initial Report of the USA to the HRC (a UN body) consisted of a rejection of international human rights standards regarding the execution of minors, the re-introduction of the death penalty, and the separation of juvenile offenders from their adult counterparts. ${ }^{57}$ That is why the USA has refused to ratify the First Optional

53. For instance, see Mutua, supra note 10; K. Wiredu, An Akan Perspective on Human Rights, in A.A. An-Na'im \& F. Deng (Eds.), Human Rights in Africa: Cross Cultural Perspectives 243-260 (Washington, DC: Brookings Institution, 1990); and E.K. Quashigah, Legitimate Governance: The Pre-Colonial African Perspective, in Quashigah \& Okafor, supra note 44, at 43.

54. See M. Seck, A Plea for Human Rights Education in Africa, 11 Human Rights Law Journal 283, at 294 (1990).

55. See Baxi, supra note 19 , at 34 .

56. See R. Higgins, Opinion: Ten Years on the UN Human Rights Committee: Some Thoughts Upon Parting, 6 European Human Rights Law Review 570, at 581 (1996).

57. See Baxi, supra note 19, at 39-48. 
Protocol to the $\mathrm{ICCPR}^{58}$ - a treaty that is intended to open the USA's legal system and social order to international juridical scrutiny. That is partly why the USA has not ratified the International Covenant on Economic, Social and Cultural Rights. That is why the USA withdrew from the UN human rights system for over thirty years when that system began to be used quite effectively by its African-American civil rights activists. ${ }^{59}$ And that is why Laurel Francis, the Jamaican member of the HRC had, while commenting on the USA's Initial Report, hoped for a new era of humility, "given the USA's penchant to jab at other nations" rejecting outside scrutiny of its own affairs. What all of these facts show is that the USA, the most powerful of the Western democracies, is itself extremely sensitive to outside scrutiny of its human rights record based on the assumption, already explicated in the previous sub-section, that since its human rights record is somehow infallible, the focus of international human rights work, including IHRE, should be on the records of other (especially Third World) states. This attitude is aptly captured by the following comment:

To most Americans the term 'human rights violation' refers to torture and atrocities in other countries, and not to homelessness, the death penalty, the lack of adequate education, or the lack of health care that exists in this country [i.e., the USA]. ${ }^{61}$

Even more worrisome is the fact that this kind of attitude is evident in the judicial pronouncements of even the US Supreme Court. Anthony Scalia, a judge of that court, is now "famous" for his argument that international human rights law was not at all material or relevant to his decision that a sixteen year old could be lawfully executed in the USA. What is more, he confirmed this attitude by explicitly subjecting the international human rights corpus to one view of American social mores, declaring most confidently that "it is American conceptions of decency that are dispositive" 62 of the question.

The last set of evidence that we want to offer in order to demonstrate the existence of this one-way traffic paradigm in both the broader human rights project, as well as in the IHRE discourse, is the nature of much of the general human rights education literature itself. With a number of remarkable exceptions, this literature tends to be based, to varying degrees, on the one-way traffic paradigm, in which an all-knowing "teacher"

58. Id., at 51 .

59. See N.H. Kaufman \& D. Whiteman, Opposition to Human Rights Treaties in the United States: The Legacy of the Bricker Amendment, 10 Human Rights Quarterly 309 (1988).

60. Cited in Baxi, supra note 19, at 52.

61. See E.L. O'Brien, Community Education for Law, Democracy and Human Rights, in Andreopoulos \& Claude, supra note 13, at 419-420. See also D.G. Thomas, Advancing Rights Protection in the United States: An Internationalized Strategy, 9 Harvard Human Rights Journal 15 (1996).

62. See Stanford v. Kentucky, 492 U.S. 361, at 369 (1989). 
(whatever the teacher's identity in the specific case) instructs an almost entirely ignorant "student" as to the nature and functions of human rights, and according to a predetermined and forever stable text. This model of human rights education, largely reproduced in specific IHRE praxis, is similar to the "banking model" of popular education that Paulo Freire has so convincingly discredited. According to Freire:

Education thus becomes an act of depositing, in which the students are the depositories and the teacher is the depositor. Instead of communicating, the teacher issues communiqués and makes deposits which the students patiently receive, memorize, and repeat. ${ }^{63}$

This teacher-student, one-way traffic model, litters the twin human rights and IHRE discursive and operational landscapes.

For instance, even though Richard Pierre Claude, who is perhaps the most published IHRE scholar, exhibits an awareness of the limitations of the teacher-student model of IHRE, he still seems to privilege it in his own work. In a paper on human rights education in the Philippines, he seems to view IHRE and other kinds of human rights education as largely constituted by human rights instruction (obviously from a teacher to her student(s). ${ }^{64}$ This assessment of his work in this area is buttressed by the fact that in another paper on the subject, he uses the metaphor of "wings" to describe the spread of human rights around the world. ${ }^{65}$ This metaphor assumes "motion." It assumes that the human rights ethos and corpus came from one part of the world and is now being flown to other parts of the world. This is evidence of a residual attachment, at the very least, to some notion of the human rights corpus being "trafficked" unidirectionally from its supposedly Western origins to its Third World destinations. However, to be fair to Claude, it must be noted that he has recognized that IHRE should involve much more than the simple provision of information to "students" and should as well be practiced in every society in the world, not just in the Third World ${ }^{66}$ Similarly, the one-way traffic paradigm, in which the student is the only "human rights learner," has, to varying extents, also framed the work of a large number of other scholars in this area. Martine Abdallah-Pretceille sees that same task as imbuing the very essence of human rights in children. ${ }^{67}$ Marie Bittner sees the task of human rights education as "developing in students an awareness as to their

63. See Freire, supra note 3, at 30.

64. See R.P. Claude, Human Rights Education: The Case of the Philippines, 13 Human Rights Quarterly 453, at 512 (1991).

65. See R.P. Claude, Human Rights Have Wings: A Note for Teachers, http://www.pdhre.org/ dialogue/wings.html.

66. Id.

67. See M. Abdallah-Pretceille, Human Rights in the Nursery School, in H. Starkey (Ed.), The Challenge of Human Rights Education 61 (London: Cassell, 1991). 
rights." ${ }^{68}$ The same applies to the work of scholars like Henry, Martin, Pettman, and Aka. ${ }^{69}$

Another variant of the one-way traffic paradigm relates to the sense that is palpable among most urban Third World elites (including most local human right activists) that in relation to the human rights ethos and so much more, there is little, if anything at all, that they can learn from the rural dwellers that live in their various countries. This is an internal version of the one-way traffic paradigm, one that is based on the same kind of devaluation of local knowledge and subaltern reflection, as is the broader Western one-way traffic paradigm. Richard Pierre Claude has described an IHRE project that was mounted in rural Thailand by Urban elite Thais in a way that suggests to us that the one-way traffic paradigm was at play there. ${ }^{70}$ Emile Francis Short has also described the IHRE projects of Ghana's national human rights commission in terms that convey a similar impression. ${ }^{71}$ Bonny Ibhawoh's report on the IHRE activities of Nigerian human rights non-governmental organizations ('NGOs') does not convey a different impression either. ${ }^{72}$

The existence of this one-way traffic paradigm in the general human rights imagination and IHRE praxis of even local urban elite activists in the Third World should not be surprising at all given the existence of extensive studies and reports on the operation of a pro-urban-bias in almost every aspect of social relations in the most Third World states. ${ }^{73}$

However, the one-way traffic paradigm authorises a heavily lop-sided Third World focus for both the broader human rights movement as well as the IHRE discourse. It views the flow of human rights knowledge(s), the very stuff of IHRE, as unidirectional, from the Western world toward the Third World. It does not, in general, see any value in, or serious possibility of, the flow of such knowledge(s) from the Third World to the Western world. Our task in this subsection of the paper is to show that not only is this paradigm inherently flawed, but that its continued

68. See M. Bittner, Human Rights Education, A Unifying Force in the Secondary School Curriculum, 19 American Secondary Education 18 (1991). See also J. Symonides, The Duty to Promote Human Rights Education, in S. Spiliopoulou Akermark (Ed.), Human Rights Education: Achievements and Challenges 11 (Turku/Abo: Institute for Human Rights, Abo Akademy University, 1998).

69. See C.P. Henry, Educating for Human Rights, 13 Human Rights Quarterly 420 (1991); J.P. Martin, Human Rights-Education for What?, 9 Human Rights Quarterly 414 (1987); R. Pettman, Taking Human Rights Education Seriously, 7 Peace Review 211 (1995); and P.C. Aka, Education, Human Rights, and the Post-Cold War Era, 15 New York Law School Journal of Human Rights 421 (1999).

70. See R.P. Claude, The Methodologies for Human Rights Education, available online at http://www.pdhre.org/materials/methodologies.html, at 27 (of printed pages).

71. See E.F. Short, The Role of the Commission on Human Rights and Administrative Justice in Ghana, 9 ASICL Proc. 185, at 192 (1997).

72. See B. Ibhawoh, Human Rights Organizations in Nigeria, unpublished report submitted to the Danish Centre for Human Rights, January 2001, at 21-22 (on file with the authors).

73. On this "urban-rural" rift, and resultant urban bias, see D. Olatunbosun, Nigeria's Neglected Rural Majority (Ibadan: Oxford University Press, 1975). 
operation will have serious negative consequences for the viability of IHRE across the globe.

Our first objection to this one-way traffic is that its underlying assumptions are, from a factual perspective, seriously flawed. As its basic premise (which is that the heaven-hell binary is largely tenable) is incorrect, it cannot itself then be sustainable as a coherent paradigm. Thus, if there is no infallible human rights heaven and there are no absolutely fallible human rights hells, then there must be a two-way traffic on matters of human rights - real dialogues in which both sides listen to each other (rather than a monologue in which one side - the Western world - is positioned as the largely all-knowing "teacher" and the other - the Third World - is positioned as the mostly ignorant "student."

Our second objection to this paradigm is that it fosters a racial (or urban-rural) and overly elitist hierarchy of peoples, in which Third World peoples are endemically viewed as much more intellectually inferior (both generally, and in the specific area of human rights praxis). Thus human rights intellectual superiority and inferiority both become racialized - those who possess human rights knowledge and who must instruct the others are almost always of European descent, while those who do not possess human rights knowledge and who must submit to instruction are almost always of Third World descent. In this case, there is very little acknowledgement of the possibility of reversing the gaze and the instruction so that the Western world may learn a few things from the Third World (even if not as much as the Third World has to learn from the Western world). As Baxi has asked:

Do we know enough beyond the 'myth' of the noble savage in what and which ways a peoples' knowledge systems are more conducive to the creation/sustenance of human rights cultures. ${ }^{74}$

In the internal political economy of the Third World itself, the human rights instructors are almost always urban elites, while the human rights students are almost always rural dwellers (who are falsely but arrogantly viewed by many urban elite as lacking in the capacity to reflect upon, articulate, and act upon their persistent suffering). In this case, there is very little acknowledgement of the possibility of reversing the gaze and the instruction so that the urban elite in the Third World may learn a few things from the mass rural dwellers (even if not as much as the rural dwellers have to learn from their urban elite counterparts). In this way is the crossfertilization of ideas across the Third World-Western divide seriously hampered. This leads us to our third objection.

Our third objection to this paradigm is that, by its very nature, it precludes genuine dialogue on an equal basis between the peoples of the Third

74. See Baxi, supra note 1 , at 2. 
and Western worlds, and instead fosters monologues and soliloquies that masquerade as "dialogues," and that this functions to hamper, even preclude, attempts to foster (through dialogues) the mass cultural legitimization of one version or another of the human rights corpus and ethos. In other words, if there is a one-way traffic in the matter of IHRE, or any human rights praxis for that matter, there is no space whatsoever for a genuine cross-fertilization (even cross-contamination) ) $^{75}$ of ideas across geo-political and cultural divides. Rather, what occurs is that the (usually Western or urban Third World) human rights "teacher" instructs (and hardly ever has a conversation of equals with) her "students" (usually Third World elites or rural dwellers). This kind of hierarchical pedagogy is highly unlikely to foster a genuine mass legitimization of the human rights corpus within Third World states. For how can a people feel the kind of sense of "ownership" of the human rights movement if they have had no input regarding the validity of the basic philosophical foundations of the human rights corpus, or as to the relevance of the priorities of the movement to their own lived experience? For the movement to simply assume that Third World peoples will follow the self-imposed leadership of the Western world without question is for it to betray a colonialist ethos that is extremely unpopular in most Third World states that we know of. Moreover, genuine dialogue is crucial not just because it fosters a sense of "ownership" of the human rights ethos and corpus among Third World peoples, but also because it can lead to the beneficial modification or enlargement of the human rights ethos or corpus. As Lynda Frost has argued, IHRE "teachers" often begin with a predetermined package of rights applicable to all and about which they seek to educate the target population or society. ${ }^{76}$ Thus, IHRE cannot be viewed as an unproblematic endeavour ${ }^{77}$ that is founded on texts that cannot be continually revised and modified. Thus, in order for it to remain open for dialogue, IHRE must refrain from being overly dogmatic. ${ }^{78}$ In this connection it is laudable that the Plan of Action for the UN Decade for Human Rights Education mentions the fostering of a genuine dialogue as one of the principal qualities of a viable IHRE praxis. $^{79}$

Our fourth and last objection to this paradigm is the related point that

75. This is a term that Makau Mutua has used in order to underscore the fact that such dialogue will not always lead to a consensus that retains one cultural form or the other in its "pure" form as the basis for a cosmopolitan human rights ethos. See Mutua, supra note 2, at 205.

76. See Frost, supra note 7, at 718. See also T. Holland, Human Rights Education for Street and Working Children: Principles and Practice, 20 Human Rights Quarterly 173, at 175-178 (1998).

77. See Baxi, supra note 1 , at 2 .

78. See Seck, supra note 54, at 298; and R. Akankwasa, Human Rights Education and the Quest for Development: The Case of Ugandan Schools, 5 East African Journal of Peace and Human Rights 105 (1999).

79. Plan of Action for the United Nations Decade for Human Rights Education, Appendix to UN Doc. A51/506/Add.1 (12 December 1996). 
the paradigm presents a false picture of the world in which the Western world hardly needs any IHRE at all. Yet this is far from the truth. Given their attitude to the extremely high cost of the drugs that could save the lives of millions of AIDS sufferers in the much poorer parts of the Third World, do many of the civil societies and transnational corporations that are domiciled in the Western world not need IHRE regarding the right to life, and the right to be human of these very sick people? Do many of the citizens and civil societies in the Western world not need IHRE regarding how not to remain "indifferent to how their elected representatives may often play God abroad," 80 especially in the Third World?

Thus, and for these reasons, not only is the one-way traffic paradigm flawed from the point of view of the validity of its underlying factual premises, it is also capable of inhibiting the mass cultural legitimization, and therefore, the eventual widespread success of both IHRE and the broader human rights movement. Again, we agree with Baxi that:

Perhaps, the first step in the activist journey of huper [i.e., human] solidarity is for HRE activists to learn from the victims of the perfidies of power rather than to presume to educate them in the struggle for survival and justice [...]. Do the victims of militarized rapes need education in the CEDAW ? ${ }^{81}$

\subsection{The abolitionist paradigm}

The identification of the existence of this paradigm in the broader human rights discourse, as well as the development of a comprehensive critique of its operation in that discourse, is largely attributable to the extraordinary fecundity of Makau Mutua's mind..$^{82}$ But since Mutua first applied a critique of that paradigm to his analysis of the politics of human rights in Africa, the paradigm has also been quite capably analyzed, and critiqued, by Celestine Nyamu. ${ }^{83}$ These critics of the abolitionist paradigm have

80. See U. Baxi, Human Rights Education: The Promise of the Third Millennium, online at http://www.pdhre.org/dialogue/third_millenium.html, at 3. This paper is re-published in Andreopoulos \& Claude, supra note 13 , at 142 . On a related point, see, generally, C. Filice, On the Obligation to Keep Informed About Distant Atrocities, 12 Human Rights Quarterly 397 (1990).

81. See Baxi, supra note 1, at 6-7 (emphasis supplied).

82. See M. Mutua, The Politics of Human Rights: Beyond the Abolitionist Paradigm in Africa, 17 Michigan Journal of International Law 591 (1996).

83. See C. Nyamu, How Should Human Rights and Development Respond to Cultural Legitimization of Gender Hierarchy in Developing Countries, 41 Harv. Int'1 L.J. 381, at 391-395 (2000). For other allusions to, or discussions of, this paradigm, see T. Nhlapo, Cultural Diversity, Human Rights, and the Family in Contemporary Africa: Lessons from the South African Constitutional Debate, 9 International Journal of Law and Family 208 (1995); and H. Lewis, Between Irua and 'Female Genital Mutilation': Feminist Human Rights Discourse and the Cultural Divide, 8 Harvard Human Rights Journal 1 (1995). 
identified local and international NGOs, and mainstream human rights scholarship as the chief enthusiasts of this paradigmatic style. ${ }^{84}$

As deployed in the broader human rights discourse, the abolitionist paradigm understands a major task of the human rights movement as the abolishment of local cultural practices that contravene the dictates of international human rights law. Culture is therefore constructed as a kind of pathological obstacle to the enjoyment of human rights that must be overcome if the relevant population is to enjoy the good life. ${ }^{85}$ As Nyamu has recently put it:

[...] these abolitionist responses create the impression that women's rights do not exist in custom or local practice, and the solution therefore lies in substituting custom and local practice with alternatives offered by national legislation or the international human rights regime. ${ }^{86}$

The abolitionist's ambition of modifying certain cruel cultural practices is not necessarily wrong in itself. What we are quarreling with in this section of the paper is the binary way in which this task is often perceived. For abolitionist human rights discourse often proceeds as if its task is to deploy a culture-free human rights corpus in order to abolish a given human rights-free culture - i.e., as if culture and human rights must always be absolutely opposed, ${ }^{87}$ as if the human rights corpus (as presently constituted) itself stands totally uncontaminated by culture. As Mutua has noted:

Human rights NGOs, especially in the West, often see themselves as modern-day abolitionists whose purpose is to spotlight an evil and advocate its eradication. Choices are cast in sharp relief, with no middle ground or moral dilemma. ${ }^{88}$

The abolitionist paradigm is problematic as a basis for IHRE because approaches based on it are all-too-often (a) de-contextualized, (b) overly ethnocentric, and/or (c) disrespectful. All three characteristics do not make for an IHRE discourse that resonates easily with mass audiences in Third World states. For this reason, all three characteristics of abolitionism do

84. For a particularly strong version of scholarly abolitionism (as identified by Nyamu, id.), see S.M. Okin, Is Multiculturalism Bad for Women?, in J. Cohen et al. (Eds.), Is Multiculturalism Bad for Women (Princeton, NJ: Princeton University Press, 1999). Another scholarly version of abolitionism (in the IHRE discourse) can be found in G. Andreopoulos, Human Rights Education in the Post Cold War Context, in Andreopoulos \& Claude, supra note 13, at 16. For an account of abolitionism in the work of both domestic and international human rights NGOs, see Mutua, supra note 82, at 604-613.

85. This is the main thrust of Rhoda Howard's arguments on "cultural absolutism." See Howard, supra note 10 .

86. See Nyamu, supra note 83 , at 393.

87. For an extended analysis of this "sense of opposition between culture and rights", see K. Engle, Culture and Human Rights: The Asian Values Debate in Context, 32 New York University Journal of International Law and Politics 291 (2000).

88. See Mutua, supra note 82, at 608. 
not make for the rapid mass cultural legitimization of the human rights corpus.

Approaches to IHRE that are based on the abolitionist paradigm are often de-contextualized because they view local practice and culture ahistorically and non-contextually as monolithic, static, ossified, and generally incapable of being transformed by the local population themselves, hence the necessity for a foreign abolitionist's unreflexive intervention. ${ }^{89}$ This is not to argue that foreigners may not provide a much needed stimulus for internal processes of change. Our argument is far from that. We agree with Makau Mutua that "outsiders are certainly an important element of Africa's [and the rest of the Third World's] problems and solutions to its crises." culture in this way, as a non-dynamic, museumified artefact, abolitionists perpetuate the myth that Third World societies are, in general, lacking in internal cultural conflict. In doing so, they silence, or hamper, the strides of local agency, thereby contributing to the sustenance of the popular mythology that the human rights ethos is absent in the philosophical traditions of each and every Third World society, and thus helping to frustrate the attempt to foster the cultural legitimization of the human rights corpus within these societies.

Such abolitionist approaches are overly ethnocentric because they too often frame difficult moral choices in simplistic terms, casting the choices in sharp relief with no middle ground, and based on the narrow perspectives of the particular abolitionist. ${ }^{91}$ While some measure of ethnocentrism is unavoidable in a world of cultural diversity, an overly ethnocentric approach to IHRE runs the real risk of becoming ineffective, in terms of its message resonating with the target population. For instance, abolitionist approaches to child labour in the Third World are too often based on romanticized and ethnocentric (and usually Western) notions of childhood that almost always assumes that the real choice that faces most poor kids in the Third World is between working and not working. In fact, in most instances, the real choice that faces these kids is between working and starving to death! This is not to endorse condemnable practices of child exploitation, but to show how an ethnocentric abolitionist IHRE ethos can largely give a counterproductive analysis of, and prognosis for the human rights problems of the Third World states.

The abolitionist approach is often disrespectful because it thrives on an image of the local culture that is often unduly hyperbolic, constructing local practices as wittingly and deliberately savage. While this is at times a useful style of advocacy, it consciously or unconsciously sustains an image of Third World cultures as deliberately savage and brutish that is all too popular in certain foreign discourses about those cultures. This is

89. See Nyamu, supra note 83 , at 394-395.

90. See Mutua, supra note 82, at 608 .

91. Id. 
an image that many Third World peoples find particularly patronizing and offensive $^{92}$ - one that does nothing to increase the chances of success of the either IHRE or the broader human rights project.

Thus, because of these problems, the IHRE project is not well served by pedagogical approaches that rely on the abolitionist paradigm.

In the foregoing section of the paper, we have identified and fleshed out the three orthodoxies that we view as constitutive of mainstream IHRE discourse and practice as well as offered a number of challenges to the orthodoxies that we view as constitutive of IHRE discourse and practice. What we will now do is to attempt to map the outlines of a way forward, a path that leads IHRE beyond the negative consequences of these orthodoxies.

\section{Re-Imagining Internatioal Human Rights Education}

The central problem is this: How can the oppressed [...] participate in developing the pedagogy of their liberation? ${ }^{93}$

The problem is not how to Christianize [or spread human rights to] Africa but how to Africanize Christianity [or the human rights corpus and ethos]. ${ }^{94}$

It is our hope that, given the critiques of the current dominant approaches to IHRE, it has become clear at this juncture that if IHRE is to succeed in actually transforming the human rights terrain of the (Third World) places to which it is usually directed, scholars and practitioners alike must rethink its content and methodology. ${ }^{95}$ IHRE must move beyond the three orthodoxies that we have identified and critiqued in this paper. It must move beyond the heaven-hell binary; the one-way traffic paradigm; and the abolitionist paradigm.

But IHRE cannot be re-thought if the human rights corpus itself continues to be conceived by some of the most powerful segments of the human rights movement as a dogma, that is no longer open for revision and enlargement. ${ }^{96}$ It must therefore remain open-ended and liable to reimagination. Only through such re-thinking can IHRE abandon effectively the stranglehold of the heaven-hell binary (that (a) draws a very firm and bright line between a "heavenly" human rights text and other alternative

92. Id., at 609 .

93. See Freire, supra note 3, at 30 (emphasis supplied).

94. This declaration was made recently by Catholic Archbishop Peter Sarpong of Kumasi, Ghana. See Newsweek, 16 April 2001, at 51.

95. See Kirpal, supra note 5, at 288.

96. We agree with Richard Devlin that the human rights discourse must remain "open-ended and revisable." See R. Devlin, Solidarity or Solipsistic Tunnel Vision? Reminiscences of a Renegade Rapporteur, in P. Mahoney \& K. Mahoney (Eds.), Human Rights for the TwentyFirst Century: A Global Challenge 992, at 992-993 (Dordrecht: Martinus Nijhoff, 1993). 
but "hellish" texts, and (b) conceptually and inaccurately sieves the globe into two starkly opposing kinds of societies, i.e., "human rights heavens" and "human rights hells"). Only through such re-thinking can IHRE abandon effectively the one-way street paradigm that conceives of education for human rights as the unidirectional flow of human rights knowledge either from the "heavenly" Western world to the "hellish" Third World, or from the "more heavenly" urban elite of the Third World to their "more hellish" rural counterparts. And only through such re-thinking can IHRE transcend effectively an abolitionist paradigm that always views, and treats with, the local cultures of the Third World as absolute obstacles to the enjoyment of the good life.

One of the ways in which IHRE can be rethought is for it to be enlarged. And one way to enlarge it is for it to accommodate more comfortably and effectively the voices that have so far felt marginalized from the mainstream human rights discourse. Issues like the systemic violence that is visited against poor minority populations in the inner cities of the USA; the misery of untreated AIDS sufferers in the Third World; maldevelopment; the rapacious activities of MNCs in the Third World; unbridled capitalism; and the penchant for too many of the leaders of the "developed" Western democracies to act abroad in ways that they would be remiss to act at home, thereby violating the human rights of people who live elsewhere; should be added to the mainstream human rights agenda in order to foster its credibility and even-handedness, and thus to contribute to its acceptance the world over as a truly global undertaking.

Again, moving beyond the three orthodoxies that we have fleshed out and critiqued in the foregoing sections of this paper requires that IHRE praxis should become much more relevant to the lives and realities of the target communities. ${ }^{97}$ And only by forging IHRE with and not for the relevant population can that praxis escape the problems caused for it by adherence to these three orthodoxies..$^{98}$ Instead of emphasising the instruction of "student" populations that are domiciled in the Third World (in the basics and virtues of a stable, ossified, human rights corpus and ethos) by their Western "teachers," IHRE ought to emphasise the fostering of a constructive and analytical dialogue among Western and Third World societies (and across the urban elite-rural internal divide within most Third World states. No less is required for a complete transformation of IHRE than its re-conception as constituted by a "group of people debating together the kind of society they would ideally like to live in" 99 and teasing out the conditions that inhibit the actualization of these ideal worlds. We

97. See the Osaka Declaration of the international Conference on Human Rights Education in the Asia-Pacific Region, http://www.pdhre.org/dialogue/osaka.html, at 2.

98. See Freire, supra note 3 , at 30.

99. See R. Robinson, Introduction: A Visitor Yet a Part of Everybody - The Tasks and Goals of Human Rights Education, in Starkey, supra note 67, at 3. 
are therefore in agreement with the Peoples' Decade of Human Rights Education that:

An aspiration of human rights education is [and ought to be] to engage individuals and communities dialectically [...] This aspiration requires more than knowledge of the content and mechanisms of international human rights instruments, which is the focus of much traditional human rights teaching. ${ }^{100}$

Such a dialectical engagement with the "students" of IHRE will in itself transgress the one-way traffic paradigm of IHRE, render the heaven-hell binary more palpably untenable, and subvert the abolitionist world view. For how can anyone sustain a belief in the validity of the heaven-hell binary when the failings of her own "heaven" (usually related to the nature of her own society and culture) are made even more obvious in an equal conversation with persons from other societies and cultures? How can anyone continue to be an abolitionist when required by the constraints of an equal conversation to speak in a much more respectful, less ethnocentric, and far more contextualized way?

Similarly, this more equal cross-cultural dialogue must not be inordinately focused on abolishing "culture" in the Third World. The current lopsidedness must be reversed to some extent. Violations of human rights in the Western world are sufficiently endemic to occupy the time, and sap the energies, of even the most enthusiastic IHRE practitioner. Moreover, as Rajsoomer Lallah and Elizabeth Evatt, respectively the Mauritian and Australian members of the HRC, have noted, there seems to be an urgent need in countries like the USA to raise the level of awareness among domestic judges and other officials, regarding the nature of the international human rights corpus and its applicability to state and society in the USA. ${ }^{101}$ Happily, a number of such programmes have now begun in the USA. ${ }^{102}$

As importantly, we are firmly convinced that if the broad and long-term objective of IHRE is to eventually transform actual social relations in the target society, then IHRE must seek to latch on to and mobilize on culturally legitimate signs, forms, artefacts, and languages that make its message more resonant, more inviting, and more palatable among the target population. Thus, the calls for the mass cultural legitimization of the human rights corpus, and of IHRE, that have been made over time by scholars such as An-Na'im, Bell, Nyamu, Mutua, Quashigah and Okafor, and Odinkalu, must be taken much more seriously and acted upon by both

100. See Towards a Pedagogy of Human Rights Education, http://www.pdhre.org/dialogue/ costarica.html, at 2 (emphasis supplied).

101. See Baxi, supra note 19 , at 53 .

102. See Claude, supra note 70, at 28. 
IHRE and the broader human rights movement. ${ }^{103}$ However, to the extent that the three orthodoxies that we have identified and critiqued are not abandoned, the mass cultural legitimization of the human rights corpus and ethos will continue to be an uphill task.

Thus, a re-imagined IHRE praxis will, in our view, discard the heavenhell binary (in favour of a more balanced view of the nature of Western and Third World societies as both fertile, if uneven, sites of oppression and human rights violations). Admittedly, many Western states seem to have a better record than most Third World states in the area of the protection of civil and political rights, ${ }^{104}$ but that narrow category of human rights does not exhaust the definition of human rights. Similarly, a reimagined IHRE praxis will, in our view, discard the one-way traffic paradigm (in favour of a two-way traffic paradigm that is the very stuff of which genuine conversations and viable pedagogies are made). And lastly, a re-imagined IHRE praxis will, in our view, shed the last vestiges of its abolitionist orientations (in favour of a less absolutist, more contextual, much more respectful, and less ethnocentric view of Third World cultures).

\section{Conclusions}

The pedagogy of the oppressed [...] must be forged with, not for, the oppressed $[\ldots] .{ }^{105}$

In conclusion, what we attempted to do in this paper is to identify, critique, and show ways of transcending three orthodoxies that, in our view have historically framed both the broader human rights discourse, as well as the IHRE discourse itself, especially as it relates to the Third World.

In our stride, we have shown that both discourses have employed the absolutism of the heaven-hell binary, and have constructed the world as composed of two kinds of sharply contrasting societies, i.e., "human rights heavens" and "human rights hells." We have also shown how both discourses have also relied on the one-way traffic and abolitionist paradigms, the one framing the task of IHRE in terms only of the instruction of the subaltern populations of the Third World by the "teachers" from the Western world (or by their own urban elite), and the other framing the task of IHRE in an unqualified way as an unequivocal battle with local culture.

103. For instance, see A. An-Na'im, Human Rights in the Muslim World, 3 Harvard Human Rights Journal 13 (1990); D. Bell, The East Asian Challenge to Human Rights: Reflections on an East-West Dialogue, 18 Human Rights Quarterly 641 (1996); Nyamu, supra note 83; Mutua, supra note 82; Quashigah \& Okafor, supra note 44; and Odinkalu, supra note 43 , at 3 .

104. See Mutua, supra note 2.

105. See Freire, supra note 3, at 30 (emphasis supplied). 
Not stopping there, we have also sought to challenge effectively each of these orthodoxies. We have attempted to expose their flaws, and show how they can lead to very problematic consequences for an IHRE praxis that aspires to success (defined in terms of the actual transformation of the target societies).

All through the paper, our overall theme has been the need to forge IHRE with and not for the Third World (or other relevant subaltern). In a similar vein, Upendra Baxi has recently described the chief task of IHRE in a world in which power is all-too-often deployed for negative ends, and in violation of human rights, as:

[...] learning how to make such power and authority [in all its myriad forms and in whatever geo-political location it is found] continuously and radically insecure, how to agonize it and ambush it, to critique it in ways which prefigure a world where power and authority would be humble before the sufferings and sorrows of the people. ${ }^{106}$

We can think of no better way for IHRE to secure its place in the hearts and minds of subaltern individuals and peoples the world over. 